\title{
Hubungan Kadar Gula Darah Dengan Tekanan Darah Pasien Diabetes Melitus Tipe 2 Di Puskesmas Sokaraja 1
}

\author{
Habib Fatah Roniawan ${ }^{*}$, Peppy Octaviani DM¹, Rani Prabandari ${ }^{1}$ \\ ${ }^{1}$ Universitas Harapan Bangsa Purwokerto, Indonesia \\ *corresponding author \\ Email: habibfatah99@gmail.com
}

Diterima : 22 September 2021

Direvisi : 11 Oktober 2021

Publikasi : 20 Oktober 2021

doi:10.52216/jfsi.vol4no2p74-78

\begin{abstract}
Type 2 Diabetes Mellitus is a condition when blood glucose in the body is not controlled due to impaired sensitivity of pancreatic cells to produce the hormone insulin. The World Health Organization (WHO) states that there are 422 million people in the world who suffer from diabetes mellitus, an increase of about $8.5 \%$ in the adult population and an estimated 2.2 million deaths. The purpose of this study was to determine the characteristics of patients with type 2 diabetes at the Sokaraja 1 Health Center and to find out how the relationship between blood sugar levels and blood pressure of type 2 diabetes mellitus patients at the Sokaraja 1 Health Center. The method used is observational analysis in perspective with a cross sectional approach. The results of this study using the Pearson correlation test showed that 46 patients were majority aged 51 to 60 (39.1\%), male 13 patients (28.3\%) female 33 patients (711.7\%), long time to diagnose diabetes mellitus greater than 1-4 years (73.9\%) and there is a relationship between blood sugar levels and blood pressure with a significance value of 0.375 .
\end{abstract}

Keywords: Diabetes, Age, Gender, Sokaraja 1 Health Center

\section{Intisari}

Diabetes Melitus Tipe 2 adalah suatu kondisi ketika glukosa darah dalam tubuh tidak dikendalikan karena gangguan sensitivitas sel $\beta$ pankreas untuk menghasilkan hormon insulin. World health organization (WHO) menyatakan bahwa ada 422 juta orang di dunia yang menderita diabetes mellitus atau meningkat sekitar 8,5\% pada populasi orang dewasa dan diperkirakan mencapai 2,2 juta kematian. Tujuan dari penelitian ini adalah untuk mengetahui bagaimana karakteristik pasien dengan diabetes tipe 2 di Puskesmas Sokaraja 1 dan untuk mengetahui bagaimana hubungan kadar gula darah dengan tekanan darah pasien diabetes tipe Mellitus 2 di Puskesmas Sokaraja 1 . Metode yang digunakan analisis observasional secara perspektif dengan pendekatan cross sectional. Hasil penelitian ini yang menggunakan uji korelasi Pearson menunjukkan bahwa 46 pasien mayoritas adalah usia 51 hingga 60 (39,1\%), laki-laki 13 pasien (28,3\%) perempuan 33 pasien (711, 7\%), lama mendiagnosis diabetes melitus besar dari 1-4 tahun (73,9\%) dan ada hubungan antara kadar gula darah dengan tekanan darah dengan nilai makna 0,375.

Kata kunci: Diabetes, Usia, Jenis kelamin, Puskesmas Sokaraja 1 


\section{Pendahuluan}

Diabetes melitus (DM) adalah sekelompok gangguan yang terjadi pada sistem metabolisme yang ditandai dengan tingginya gula darah serta terjadinya perubahan metabolisme lemak dan protein yang disebabkan oleh sekresi insulin dari sensitivitas insulin. DM ditandai dengan pembentukan AGEs (Advance Glycation End Products) produk yang menyebabkan komplikasi mikrovaskular atau makrovaskular (DiPiro et $a l$, 2020).

Berdasarkan World Health Organization (WHO) menjelaskan bahwa terdapat 422 juta orang didunia mengalami diabetes mellitus dengan populasi penderita pada orang dewasa mencapai 2,2 juta kematian. Diperkirakan persentase angka kejadian diabetes melitus dinegara-negara berkembang pada penderita yang berusia di bawah 70 terus mengalami peningkatan yakni sekitar 600 juta orang pada tahun 2035 (Kemenkes RI, 2018).

Data yang diperoleh dari (Kemenkes RI, 2018), menunjukkan prevalensi diabetes melitus (DM) berdasarkan diagnose dokter pada umur $>15$ tahun menurut provinsi adalah sebesar $20 \%$. Pasien dengan diabetes melitus 2 menyentuh angka prevalensi diabetes melitus tipe 2 sebesar 90 sampai $95 \%$ dari populasi umum penderita diabetes (kanan, 2012). Berdasarkan (Dinkes Banyumas, 2020) tentang jumlah diabetes mellitus di Kabupaten Banyumas pada 25.744, yang menerima layanan kesehatan berdasarkan standar 24.600 atau $95,6 \%$.

Tanto Dan Hustrini (2014) menyatakan bahwa DM yang ditandai dengan kelebihan kadar gula darah (hiperglikemia) Adalah salah satu faktor risiko terjadinya tekanan darah tinggi atau hipertensi, menurut hasil riset ADA pada tahun (2017) dua dari tiga penderita DM mempunyai tekanan darah yang tinggi. Arti dari hubungan tekanan darah dengan kadar gula darah ialah pasien memperhatikan serta mengendalikan tekanan darah dan dula darah menuju ambang normal. Dalam sebuah studi diperoleh hasil bahwa penurunan TD 5-10 mmHg dapat menurunkan risiko kematian pada penderita DM tipe 2 sebanyak tiga kali, risiko stroke $50 \%$ dan risiko gagal jantung sebanyak tiga kali dibanding dengan penderita hipertensi yang tidak terkendali. (Ichsantiarini, 2013).

\section{Metode Penelitian}

\subsection{Rancangan Penelitian}

Desain yang digunakan analitik observasional cara perspektif dan pendekatan Cross sectional. Pengambilan data dilakukan bulan Juli 2021. Populasi penelitian ini pasien diabetes melitus tipe 1 dan 2 yang berdomisili di wilayah kerja Puskesmas Sokaraja 1. Teknik sampling menggunakan purposive sampling dan penderita DM tipe 2 sebagai responden dengan kriteria yang telah ditentukan oleh peneliti.

Variabel independen dalam penelitian ini adalah kadar gula penderita DM tipe 2 sedangkan variabel dependen dalam penelitian ini adalah tekanan darah penderita DM tipe 2. Instrument yang digunakan adalah instrumen primer, yaitu data yang dilakukan oleh para peneliti untuk menyelesaikan masalah yang dikelola (Sugiyono, 2015). Sementara alat pengukuran dalam penelitian ini adalah form pengambilan data, mengukur kadar gula darah menggunakan alat glucometer dan pengukuran tekanan darah menggunakan tensimeter. Teknik pengumpulan data diperoleh dari nama, usia, jenis kelamin dan lama terdiagnosa diabetes melitus.

\subsection{Analisis Data}

Uji analisis yang digunakan univariate dan bivariate. Analisis univariate dipakai untuk mengetahui persentase tekanan darah dan gula darah, usia dan jenis kelamin. Sementara analisis bivariate tes statistik yang digunakan untuk variabel dilakukan tes korelasi Pearson dengan $\alpha$ $=0,05$ menggunakan SPSS 26 Windows untuk mengetahui apakah ada perbedaan dua variabel tersebut.

\section{Hasil dan Pembahasan}

3.1. Karakteristik pasien prolanis di Puskesmas Sokaraja 1 
Tabel 1 menunjukkan hasil studi tentang karakteristik responden didapatkan paling banyak responden berusia 51-60 tahun dan usia 61-70 tahun sebanyak 18 responden $(39,1 \%)$. Hasil ini sejalan dengan penelitian yang dilakukan (Raphaeli, 2017) didapatkan sebagian besar dari jumlah kejadian kasus DM tipe 2 diderita oleh responden yang berusia 40 tahun. Penelitian oleh (Inoue et al, 2012) memperoleh hasil bahwa jumlah penderita DM terbesar diderita oleh kelompok yang memiliki usia 46- 53 tahun. karakteristik responden separuh lebih berjenis kelamin perempuan sebanyak 33 responden $(71,7 \%)$. Sejalan dengan penelitian yang dilakukan oleh (Hartani, 2014) menemukan bahwa $62,8 \%$ responden yang paling banyak ditemukan perempuan dibandingkan laki - laki. Perempuan memiliki risiko lebih besar untuk menderita diabetes melitus daripada laki-laki karena secara fisik wanita memiliki peluang peningkatan indeks masa tubuh yang lebih besar sindrom siklus bulanan (premenstrual syndrome) pasca menopause yang membuat distribusi lemak tubuh menjadi mudah terakumulasi akibat proses hormonal tersebut sehingga wanita berisiko menderita diabetes mellitus (Wahyuni, 2014).

Karakteristik responden separuh lebih berjenis kelamin perempuan sebanyak 33 responden $(71,7 \%)$. Sejalan dengan penelitian yang dilakukan oleh (Hartani, 2014) menemukan bahwa 62,8 \% responden yang paling banyak ditemukan perempuan dibandingkan laki - laki. Perempuan memiliki risiko lebih besar untuk menderita diabetes melitus daripada laki-laki karena secara fisik wanita memiliki peluang peningkatan indeks masa tubuh yang lebih besar sindrom siklus bulanan (premenstrual syndrome), pasca menopause yang membuat distribusi lemak tubuh menjadi mudah terakumulasi akibat proses hormonal tersebut sehingga wanita berisiko menderita diabetes mellitus (Wahyuni, 2014).

Karakteristik responden lama terdiagnosa diabetes melitus. < 1 sebanyak 1 orang $(2,2 \%), 1-$ 4 tahun sebanyak 34 orang $(73,9 \%), 5-10$ tahun sebanyak $9(19,6 \%)$ responden serta responden dengan lama menderita DM tipe 2 lebih dari 10 tahun sebanyak 2(4,3\%) responden. Sejalan dengan penelitian (Lima et al, 2018) bahwa dalam surveinya dia menyatakan bahwa pasien dengan DM yang menderita DM selama lebih dari 10 tahun, terutama pada lansia memiliki skor kualitas hidup terburuk terutama dalam aspek fisik , hubungan sosial, independensi dan partisipasi sosial.

Juga dijelaskan bahwa independensi dan hubungan sosial pada pasien dengan DM akan berkurang setiap tahun karena kelemahan penyakit. Juga $<10$ tahun menderita DM, kemungkinan terjadi keterbatasan kemampuan aktivitas, rasa sakit dan ketidaknyamanan (Lima et

Tabel 1. Karakteristik pasien prolanis

\begin{tabular}{|c|c|c|c|c|}
\hline Variabel & Indikator & Frequency & Percent & Cumulative Percent \\
\hline \multirow{3}{*}{ Jenis Kelamin } & Laki-laki & 13 & 28,3 & 28,3 \\
\hline & Perempuan & 33 & 71,7 & 100,0 \\
\hline & Total & 46 & 100,0 & \\
\hline \multirow{7}{*}{ Usia } & $<41$ tahun & 1 & 2,2 & 2,2 \\
\hline & $41-50$ tahun & 1 & 2,2 & 4,3 \\
\hline & $51-60$ tahun & 18 & 39,1 & 43,5 \\
\hline & $61-70$ tahun' & 18 & 39,1 & 82,6 \\
\hline & $>71-80$ tahun & 6 & 13,0 & 95,7 \\
\hline & >80 tahun & 2 & 4,3 & 100,0 \\
\hline & Total & 46 & 100,0 & \\
\hline \multirow{5}{*}{ Lama Terdiagnosa DM } & $<1$ tahun & 1 & 2,2 & 2,2 \\
\hline & 1-4 tahun & 34 & 73,9 & 76,1 \\
\hline & 5-10 tahun & 9 & 19,6 & 95,7 \\
\hline & $>10$ tahun & 2 & 4,3 & 100,0 \\
\hline & Total & 46 & 100,0 & \\
\hline
\end{tabular}


$a l, 2018)$.

3.2. Hubungan Kadar Gula darah dengan tekanan darah

\begin{tabular}{|c|c|c|c|c|}
\hline & & $\begin{array}{c}\text { Kadar } \\
\text { Gula } \\
\text { Darah } \\
(\mathrm{N}=46)\end{array}$ & $\begin{array}{c}\text { Tekanan } \\
\text { Darah } \\
\text { Sistolik } \\
(\mathrm{N}=46)\end{array}$ & $\begin{array}{c}\text { Tekanan } \\
\text { Darah } \\
\text { Diastolik } \\
(\mathrm{N}=46)\end{array}$ \\
\hline \multirow{2}{*}{$\begin{array}{c}\text { Kadar Gula } \\
\text { Darah }\end{array}$} & $\begin{array}{c}\text { Pearson } \\
\text { Correlation }\end{array}$ & 1 & $.375^{*}$ & $.386^{* *}$ \\
\hline & Sig. (2-tailed) & & .010 & .008 \\
\hline \multirow{2}{*}{$\begin{array}{c}\text { Tekanan } \\
\text { Darah } \\
\text { Sistolik }\end{array}$} & $\begin{array}{c}\text { Pearson } \\
\text { Correlation }\end{array}$ & $.375^{*}$ & 1 & $.488^{* *}$ \\
\hline & Sig. (2-tailed) & .010 & & .001 \\
\hline $\begin{array}{l}\text { Tekanan } \\
\text { Darah }\end{array}$ & $\begin{array}{c}\text { Pearson } \\
\text { Correlation }\end{array}$ & $.386^{* *}$ & $.488^{* *}$ & 1 \\
\hline Diastolik & Sig. (2-tailed) & .008 & .001 & \\
\hline
\end{tabular}

Berdasarkan tabel 2 menunjukkan bahwa kadar gula darah dengan tekanan darah di puskesmas sokaraja 1 saling berhubungan karena hasilnya 0,008 untuk darah diastolik dan 0,375 untuk darah sistolik. Hasil ini sejalan dengan penelitiannya (Setiyorini et al, 2018) dimana dalam penelitian ini didapatkan hasil tertinggi yaitu pada responden dengan kadar gula darah normal dan tekanan darah normal yaitu sebanyak 27 (36\%) responden dan $42(56 \%)$ responden memiliki gula darah dan tekanan darah normal. Uji bivariate menggunakan sperman rank juga menunjukkan hasil p-value 0,017 hasil ini mengartikan bahwa ada korelasi yang signifikan antara variabel kadar gula darah dengan variabel tekanan darah pada pasien DM tipe 2 .

Nilai korelasi koefisien didapatkan sebesar 0,274 yang menyatakan bahwa kekuatan hubungan antara dua variabel cukup kuat. Hasil tersebut menjelaskan bahwa kadar gula pada penderita DM tipe 2 bisa mengakibatkan turbulensi tekanan darah yang tinggi. Didukung oleh penelitian (Mutmainah, 2012) yang menerangkan bahwa ada hubungan yang signifikan antara kadar gula darah dan hipertensi pada pasien DM tipe 2.
Dalam hiperglikemia, glukosa darah mengikuti dinding pembuluh darah. Kemudian akan ada proses pembakaran oleh oksigen (oksidasi) antara gula darah dan protein yang terjadi di pembuluh darah yang dapat menyebabkan glycation end product (AGEs) . AGEs dapat menyebabkan kerusakan pada bagian dalam dinding pembuluh darah dan menarik kolesterol ke dinding pembuluh darah yang menghasilkan reaksi inflamasi. sel koagulasi (trombosit dan sel darah merah (leukosit) ikut berperan dalam proses penggumpalan plak menyebabkan pembuluh darah tidak elastis, kaku, keras dan akhirnya terjadi penyumbatan dan mengakibatkan hipertensi (Fatimah, 2015).

\section{Kesimpulan}

Hasil pemantauan karakteristik pasien diabetes melitus tipe 2 di Puskesmas Sokaraja 1 menunjukkan bahwa dari 46 pasien terdapat 18 pasien yang usianya 51 - 60 tahun dan 2 pasien yang usianya di atas 80 tahun. Pasien yang berjenis kelamin laki-laki sebanyak 13 pasien $(28,3 \%)$ dan perempuan sebanyak 33 pasien (71,7\%). Lama terdiagnosa diabetes melitus terdapat 34 pasien yang lama terdiagnosisnya 1 4 tahun dan terdapat 2 pasien yang lama terdiagnosa nya lebih dari 10 tahun. Kesimpulan berisi rangkuman singkat atas hasil penelitian dan pembahasan.

Adanya hubungan kadar gula darah dengan tekanan darah pasien diabetes melitus tipe 2 dengan nilai signifikan sebesar 0.375 (kurang dari 0,05 ) untuk tekanan darah sistolik dan nilai signifikan sebesar 0,386 (kurang dari 0,05) untuk tekanan darah diastolik.

\section{Daftar Pustaka}

American Heart Association. (2017) . Guidline For Prevention, Detection and Management of High blood Pressure in Adults.

Chris Tanto \& Hustirini Ni Made. 2014. Hipertensi. Kapita Selekta Kedokteran. Essentials of Medicine. Edisi IV. II. Jakarta : Fakultas Kedokteran Universitas Indonesia

Dinkes Banyumas. (2020). Profil Kesehatan Kabupaten Banyumas Tahun 2019. Journal 
of Chemical Information and Modeling, 53(9), 52-53.

DiPiro, J. T., Yee, G. C., Posey, L. M., Haines, S. T., Nolin, T. D., \& Ellingrod, V. (2020). Pharmacotherapy: A Pathophysiologic Approach, Eleventh Edition.

Fatimah, R.N. 2015. Diabetes Melitus Tipe 2. Jakarta: J MAJORITY. Vol. 4, No. 5:93-99.

Hilawe, E. H., Yatsuya, H., Kawaguchi, L., \& Aoyama, A. (2013). Differences by sex in the prevalence of diabetes mellitus, impaired fasting glycaemia and impaired glucose tolerance in sub-Saharan Africa: a systematic review and meta-analysis. Bulletin of the World Health Organization, 91(9), 671682D. https://doi.org/10.2471/blt.12.113415

Inoue, M., Inoue, K., \& Akimoto, K. (2012). Effects of age and sex in the diagnosis of type 2 diabetes using glycated haemoglobin in Japan: The Yuport medical checkup centre study. PLoS ONE, 7(7), 2-5. https://doi.org/10.1371/journal.pone.0040375

Kemenkes RI. (2018). Hasil Riset Kesehatan Dasar Tahun 2018. Kementrian Kesehatan RI, 53(9), 1689-1699.

Lima, L. R. de, Funghetto, S. S., Volpe, C. R. G., Santos, W. S., Funez, M. I., \& Stival, M. M. (2018). Quality of life and time since diagnosis of Diabetes Mellitus among the elderly. Revista Brasileira de Geriatria e Gerontologia, 21(2), 176-185. https://doi.org/10.1590/198122562018021.170187

Mutmainah, I. (2012). Hubungan Kadar Gula Darah Dengan Hipertensi Pada Pasien Diabetes Melitus Tipe 2 Di Rumah Sakit Umum Daerah Karanganyar Naskah. Naskah Publikasi.

Raphaeli, H. K. (2017). Hubungan Kadar Gula Darah Sewaktu dengan Tekanan Darah pada Pasien Diabetes Melitus Tipe 2 yang Baru Didiagnosis di Poliklinik Penyakit Dalam RSU Siti Hajar Medan Tahun 2015-2017. http://repositori.usu.ac.id/handle/123456789/ 4676
Sugiyono. 2015. Metode Penelitian Kuantitatif \& Kualitatif. Bandung : Alfabeta

Setiyorini, E., Wulandari, N. A., \& Efyuwinta, A. (2018). Hubungan kadar gula darah dengan tekanan darah pada lansia penderita Diabetes Tipe 2. Jurnal Ners Dan Kebidanan (Journal of Ners and Midwifery), 5(2), 163-171. https://doi.org/10.26699/jnk.v5i2.art.p163171. 